\title{
Discretionary Time of Chinese College Students: Activities and Impact of SARS-Induced Constraints on Choices
}

\author{
He Yang • Susan Hutchinson · Harry Zinn • Alan Watson
}

Accepted: 21 July 2010/Published online: 3 August 2010

(C) Springer Science+Business Media B.V. 2010

\begin{abstract}
How people make choices about activity engagement during discretionary time is a topic of increasing interest to those studying quality of life issues. Assuming choices are made to maximize individual welfare, several factors are believed to influence these choices. Constraints theory from the leisure research literature suggests these choices are heavily influenced by intrapersonal, interpersonal and structural constraints. Within these constraints, the individual is motivated to make choices that maximize perceived personal welfare. Leisure affordance theory focuses on these motivations by suggesting the importance of more positive influences on choices within a set of constraints. In this study, an inventory of discretionary time activities and reasons for choosing these activities were documented for a sample of Chinese college students. Because data were collected during an unanticipated SARS epidemic, the impact of the SARS crisis on students' daily choices was also examined in detail. Despite the constraints imposed by SARS and the attendant suspension of off-campus activities, some students did not perceive a change of daily life as a result, while others perceived positive changes in attitudes and behavior. Findings shed light on students' experiences during a time of rapid change in Chinese society and higher education. Decisions made during this influential time of life are important because they may affect students' future choices related to leisure and discretionary time.
\end{abstract}

Keywords Discretionary time activity - Chinese college students · SARS · Constraints · Affordance

H. Yang (ه)

The Pennsylvania State University, 1655 Elk Creek Road, Greenough, MT 59823, USA

e-mail: yanghe2004@yahoo.com

S. Hutchinson

Dalhousie University, Stairs House, 6230 South Street, Halifax, NS B3H 3J5, Canada

H. Zinn

The Pennsylvania State University, 701C Ford Building, University Park, PA 16802, USA

A. Watson

The Aldo Leopold Wilderness Research Institute, 790 E Beckwith, Missoula, MT 59801, USA 


\section{Introduction}

A topic closely related to the quality of life and personal welfare literature is how people allocate unobligated time on a daily basis (e.g., Goodin et al. 2005; Krueger et al. 2009). In studies of how people spend their time, unobligated time has commonly been differentiated from obligated time, and both of these vary across cultures and across the human life cycle within cultures. Obligated time commonly includes specific periods of time consumed for paid work (or class time for students, if their education is their current obligation), household chores and time for personal care. Robinson (1977) referred to these tasks as obligatory tasks. The remaining unobligated time has been described sometimes as free time and sometimes as discretionary time (Goodin et al. 2005). Free time is commonly that time left in the day outside of time used for obligatory tasks (Andorka 1987), and discretionary time is more commonly the time people have above and beyond the time needed for obligatory tasks (Goodin et al. 2005), a very fine distinction. Sometimes people spend some of their discretionary time on obligatory tasks, more than is necessary to accomplish the tasks themselves, and commonly by choice (Goodin et al. 2005). A person might cook a much fancier, tastier, or healthier meal than is minimally necessary, because he or she enjoys cooking. Or students may spend more time studying than minimally necessary, partly because they are motivated to succeed and partly because they are in an environment that encourages participation in learning activities. Like free time activities, enjoyable obligatory tasks can consume discretionary time and contribute to quality of life (Goodin et al. 2005).

It has been widely agreed among those who study how college students spend their discretionary time that out-of-class activities can contribute in many ways to valued outcomes of a college education (Kuh 1995). In U.S. colleges, what takes place outside the classroom has been found to be the most significant aspect of their educational experience for 40 percent of students (Moffatt 1988), and participation in extracurricular activities has been found a more accurate predictor of workplace competence than grades (Howard 1986). As argued by Kuh (1995), out-of-class experiences present students with personal and social challenges, encourage them to develop more complex, nuanced views on personal, academic, and other matters, and provide opportunities for synthesizing and integrating material presented in the formal academic program (classes, laboratories, studios). Research on discretionary time choices generally, and out-of-class experiences of college students specifically, despite its widely acknowledged importance in Western academia, has been scarce in China.

In China, dramatic industrial, economic, governmental and social changes have been happening over the past two decades (e.g., Lewis and Xue 2003; Larmer 2006), which inevitably have affected the lives of its citizens in many ways, therefore attracted attention from the field of life quality research (e.g., Smyth et al. 2010). In the wake of profound economic and societal transformation, remarkable changes have also occurred in Chinese higher education (Duan 2003): the merging of colleges and universities, an effort to part from the former Soviet Union's model of single disciplinary universities and draw closer to the Western model of common comprehensive universities; enrollment expansion, with universities accepting more students than ever; the introduction of tuition paid by families instead of government subsidies; the cancellation of guaranteed job placement for graduates, which requires all college graduates find their own employment; and removal of age and marital status limits to compete in college entrance examinations, opening opportunities for adults older than 25 and/or married individuals to enter colleges and universities. Certain top universities even began to admit first-year students without assigning them to 
specific majors (e.g., Duan 2003; Cheng and Zhou 2003), a practice previously not witnessed in China.

Implications of these new policies may include stronger economic pressure for students, more intense job competition after graduation, more freedom and individual power to make one's own choices, and a student population that is more demographically diverse. A student's life is likely affected by this transformation of higher education in China. For example, Duan (2003) observed that today's college students in China are different from the previous generation in that they are more cosmopolitan with more broad interests, they are more engaged in sports and more likely to participate in clubs, competitions, performances and festivals, and many students now try to get work-study positions on campus or part-time work to help pay for college tuition.

As China experiences rapid transformation in every area, higher education has been regarded increasingly important by both the Chinese government and Chinese families, and there is widespread anticipation that today's college students are likely to have a further transformation influence on the future China (e.g., Lewis and Xue 2003; Duan 2003; Keku xuexi 2005). It is important to understand how students experience life in the new contexts of Chinese higher education, and how student life today is anticipated to influence their lives in the future. The study reported here focuses on Chinese college student experiences outside the classroom, or during their discretionary time, and how they make decisions about use of this time.

To understand Chinese college student decisions about discretionary time, a research project was conducted in 2003 on a university campus in China. As plans for the study were being finalized during spring 2003, an alarming epidemic of Severe Acute Respiratory Syndrome (SARS) spread rampantly through China, infecting thousands of people, claiming hundreds of lives, and imposing many new constraints on how people allocated their time (Kamps and Hoffmann 2003). In an effort to keep SARS under control, China temporarily closed theaters, Internet cafes, discos and other recreational facilities. Many Chinese universities also took strict measures to keep students on campus and keep visitors out. Designing interview protocols in late April and early May, when the SARS crisis was serious, the researcher expected that data collection was likely to be conducted during a time when students were confined to campus. To address this issue, the focus of this research shifted to include an examination of the impact of SARS and related constraints on students' activities imposed by university officials.

To better understand students' choices about out-of-class activities and address constraints imposed on student activities during SARS, the theoretical frameworks of leisure constraints (Crawford et al. 1991) and affordance (Mannell and Kleiber 1997) have immediate relevance. Although these frameworks originally focus on explanations of leisure behavior choices, as social psychological theories, they can provide a framework for understanding of discretionary time activity participation, also.

\subsection{The Chinese College Context}

Tao et al. (2000) described briefly some differences in the Chinese college context from American universities: Most Chinese universities are in large or medium-sized cities, so many young people travel far away from home to another province or city to attend a university. Unlike individual-based student management in Western universities, the system for student management in Chinese universities is group-based. Most undergraduate students share a room with the same cohort of six or seven other students throughout their university years. The students are usually divided into classes by their majors, and these 
students then take all or most of their classes together, take part in university activities together (e.g., sports competitions), and even live in several dorm rooms together. The number of students sharing a dormitory room has recently decreased to four students at many universities, and campus utilities have improved in many places (Duan 2003). Nonetheless, the Chinese college context remains very different from that in North America. Therefore, in an exploration of discretionary time choices, it is important to not apply any pre-limited choices developed from Western investigations.

In a typical Chinese university, there are usually four class periods scheduled in the morning, each for $50 \mathrm{~min}$, starting at $8 \mathrm{am}$. It has been a common practice that two class periods are assigned each day for each course meeting. A school-wide lunch and nap break is observed between 12:00 and 2:00 pm (in summer the break extends to 2:30 pm, sometimes even to 3:00 pm). In the afternoon there may be two class periods scheduled, in summer between 2:30 pm and 4:20 pm. In the evening there may be two class periods scheduled for some students, usually starting at 7:00 pm. Out of class, students may be required to attend group-based activities such as political meetings, other organized class activities, or annual track and field contests which could last several days.

\subsection{Leisure Constraints}

Leisure constraints theory (Crawford et al. 1991) was developed within the leisure context and aimed at explaining some discretionary time choices, particularly leisure participation and nonparticipation. Presented as a hierarchical, sequential model, leisure constraints theory addresses why people do not take part in certain leisure activities, or what hinders people from engaging in particular leisure activities. According to this theory, people experience three types of constraints: intrapersonal, interpersonal, and structural. Intrapersonal constraints refer to factors such as personal attitudes and beliefs. If a person is not hindered by intrapersonal constraints, he or she may have a leisure preference, but may still face interpersonal constraints, such as a lack of an appropriate co-participant, or disapproval from family and friends. If a person is not hindered by either intrapersonal or interpersonal constraints, there may be structural constraints due to lack of time and money or lack of facilities that prohibits the person from participating in the leisure activities he or she desires. Institutionally-imposed constraints, such as imprisonment or regulations imposed to control the spread of SARS, are structural constraints. Constraints may interact simultaneously and reciprocally. For example, even the anticipation of interpersonal and structural constraints may impose intrapersonal constraints in the form of a self-protective lack of interest (Jackson et al. 1993). Although leisure constraints theory was developed in North America, a comparison study of Canadian and mainland Chinese students (Walker et al. 2007) demonstrated that, despite cultural differences, Chinese students were more intra- and interpersonally constrained than Canadian students, and the hierarchical leisure constraints model was applicable across the two cultures.

Some disagree that a person's participation (or not) in leisure is viewed basically as the result of constraints negotiation. For example, Samdahl and Jekubovich (1997) questioned the premises, objectives, and insights of leisure constraints research; Henderson (1997) argued that dynamic and cumulative effects may be more important. Responding to the many criticisms, Jackson (2000) rightly suggested some changes in leisure constraints research, such as broadening the range of criterion variables related to structural constraints, recognizing broader contextual issues for leisure, investigating processes of leisure constraints negotiation and circumstances which enhance success in achieving leisure 
goals, and incorporating qualitative methods into the research to increase depth of understanding.

\subsection{Leisure Affordance}

Leisure affordance, according to Mannell and Kleiber (1997), refers to "conditions that will promote and support satisfying leisure styles" (p. 345). As stated by Mannell and Kleiber (1997), "the potential for facilitating leisure participation and enhancing leisure experiences can be understood through the leisure constraints and leisure affordances that are present in the environment or can be created within the environment, as well as the psychological factors within individuals that influence the perception of constraint or affordance" (p. 346).

Affordance, a term from ecological psychology, characterizes what the environment offers a perceiver; it is defined by the constraints as well as the possibilities for action that are present in a particular situation (Gibson 1977; Greeno 1994). As forcefully argued by Kleiber et al. (2005), rather than being the opposite of affordances, constraints serve to define them. For example, elimination of constraints does not guarantee participation. Furthermore, in a context that offers the prospect for an experience that is strongly desired, the constraints recognized as part of that context may simply be accepted. Kleiber et al. (2005) clearly stated that an affordance represents the environmental conditions that elicit motivation (interest, enthusiasm, approach, etc.) in conjunction with felt needs, and affordances are only fully perceived through action that brings the conditions into interaction with the individual.

Kleiber et al. (2005) also argued that specifying affordance in social situations can provide a more complete description of behavior and experience than has been the case in previous leisure research, since social psychology of leisure is concerned with understanding and studying leisure behavior and experiences of individuals in social situations (Mannell and Kleiber 1997). They stated that sensitivity to social affordances also changes as a result of a person's characteristics, actions and interactions, which makes social affordance difficult to specify. They believed that specification of affordances for leisure should be an important subject for both research and practice. To summarize, as argued by Kleiber et al. (2005), examining leisure opportunities and participation through both perceived constraints (usually considered negative factors) and perceived affordances (usually considered positive factors) may shed new light on the process of leisure participation and provide new directions for research.

\section{Purpose of Study}

The main purpose of this study was to explore discretionary time activity choices of Chinese college students, and how students perceived the impact of an institutionallyimposed, SARS-related structural constraint on their choices. As a full understanding of behavior can only be achieved when a researcher knows what it means to the person who performed it (Mannell and Kleiber 1997), student-perceived reasons for participation in discretionary time activities were also explored. Research questions that guided this study included: (a) What activities do Chinese university students participate in during discretionary time (including everything not directly related to class, household chores or personal care tasks)? (b) What factors influence their decisions regarding participation in 
these activities? and (c) What impact does an institutionally-imposed structural constraint, such as the SARS-related campus closure, have on these choices?

\section{Methods}

Aimed at describing recent choices and understanding these choices from the students' own view rather than from the perspective of an "expert" who passes judgment on participants (Creswell 1998), this study took the approach of qualitative inquiry and interpretation. Although this study was one of several concurrent projects involving college students in China, the procedures discussed here are restricted to this study.

\subsection{Participants and Study Context}

Participants were recruited from a large university in China. This university was chosen because it was a large, comprehensive university that attracted students nationwide and it was accessible to the researcher during travel and access restrictions imposed in response to the 2003 SARS epidemic. Because understanding the daily life of typical college students was the focus of this study, "ordinary" cases were more welcome than unusual cases. Participants were obtained by a combination of purposeful and snowball sampling. The purposeful part of the selection methodology was to make sure a diversity of students with different family backgrounds, majors, school standings and social involvement levels were chosen. Sixteen participants ( 8 men, 8 women) 19-25 years old were recruited, including three first-year students, four sophomores, five juniors, and four seniors from 11 different majors. Participants were from 8 provinces and 2 autonomous regions, with half from urban families, and half from rural China.

The university had two campus sites, located within Xi'an, the ancient capitol of China and a thriving urban center of over seven million people at the time of the study. About half of the students, who majored in physical sciences, lived on the older main campus. Students in other majors had been relocated to a new campus in the summer of 2002. Shuttle buses and public transportation were available between the two campuses. Faculty and staff lived in the residential area of the old campus, and traveled by school shuttle from the old campus to work on the new campus when needed. Like most Chinese universities, this university has walled campuses and guards at each gate. Students are required to live in dormitories on campus, with four to six students sharing one dorm room. On old campus, dorm rooms do not have bathrooms; on the new campus, however, each dorm room has a bathroom. Similar to most Chinese universities, this university used a two-semester system, with spring semester in session roughly between February and July.

After the Chinese government disclosed on April 20 that the number of SARS cases was many times higher than previously reported, university authorities quickly took measures against SARS. Effective April 25, there was strict control over who was permitted to enter or leave campus. A special pass authorized by school authorities was required; no student was allowed to leave campus, and no visitors were allowed in. This control was relaxed in early June as the threat of SARS seemed to have passed, although the "sealing" of the university was not officially lifted until June 20. During this period, as part of the efforts to "build the body against SARS," school authorities encouraged physical activities. 


\subsection{Data Collection}

Data were collected between June 12 and June 27, using time diaries and semi-structured interviews. Time diaries in this study were not intended for quantitative analysis and comparisons, but used as a way to provide common ground between the researcher and participants for discussions in interviews about discretionary time activities. This was because (a) the purpose of the study was to generate a spectrum of activities and understand reasons for discretionary time choices from the participants' view, not to analyze time allocation or the rate of participation of the small sample of 16 participants, and (b) the number of observations was sufficient for this qualitative research, but neither designed nor meaningful for quantitative analysis. Therefore, each participant was asked to provide complete accounts of what he or she did for a period of 3-6 days, depending on how long the participant was available or willing to keep the time diaries without feeling extra burden. For each single day, the participant was asked to fill out a time diary sheet that included items such as time and duration of activity, location, description of the activity, other participants, what else the person did at the same time, and whether the person considered this activity an obligation or something else. As it turned out, time diaries were recorded between June 12 and June 21 . Some participants even voluntarily filled out extra time diary sheets based on memory to show what a "typical" day would be like in their daily life. From these time diaries, general information about the structure and types of out-of-class activities for each participant was obtained to provide a foundation for further in-depth interviews. It is worth pointing out that time diaries were not heavily relied upon to provide information on SARS restrictions; most information about SARS restrictions would be obtained from interviews.

In-depth interviews, conducted between June 19 and June 27 (shortly before and continuing after the campus "sealing" was officially lifted on June 20, when the memory of the SARS experience was still fresh), were used to collect further data on activities, perceptions of participants regarding the activities and the impact of SARS on the choices they made. The interview protocol included questions about the participant's personal background (e.g., age, major, location of family home); probing for activities that might be missing from the time diary (e.g., activities they usually did but were not recorded in the diary and what their friends and classmates did that was not included in the activity list); questions about the impact of SARS (e.g., whether SARS had changed their way of life, and what the changes were); and further questions about their observations of discretionary time activities (e.g., the most common discretionary time activities among college students, and why they believe students participate in such activities). As interviews were semistructured, each participant was likely to be asked specific questions based on the information provided in the earlier time diary. All interviews were audio-tape recorded.

\subsection{Data Analysis}

After the time diary from each participant was collected, recorded activities were briefly summarized (e.g., what discretionary time activities this participant seemed to engage in) for each participant to provide a foundation for the interviews. After all recorded interviews were transcribed into word-processor files in the original language-Chinese-the data files were read multiple times and examined in Chinese deductively, based on research questions (e.g., what activity choices they made and why) and more particularly, interview questions (e.g., what the most common discretionary time activities were among college students). Answers to each question from each participant were extracted and translated 
into English. These answers to activity choice questions were put into a spreadsheet according to participant and interview question. After the data spreadsheet was completed in English, it was further analyzed and interpreted by the author.

As to the impact of SARS, within-case analysis was used to look for possible changes in each student's activity patterns as a result of SARS. Afterwards, a cross-case analysis was undertaken. The data were examined deductively, based on key terms associated with the research questions and the theoretical construct of affordance and inductively, based on terms or concepts evidenced in the data. The first author discussed each case and the common themes with an experienced qualitative social science researcher who also examined the data; and agreement on the coding framework was reached through discussion. The first author then coded all the transcripts according to the coding framework.

\section{Findings}

\subsection{Discretionary Time Activities of Chinese College Students}

The combination of time diaries and interviews generated a comprehensive inventory list of out-of-class activities (composed of both obligatory and discretionary time activities) participated in by these Chinese college students, including activities participants were involved in before SARS or activities they would have participated in if SARS had not happened. This inventory list is a compilation of (a) activities recorded in the time diaries, (b) activities not recorded in the time diaries but reported by participants during follow-up interviews, and (c) activities participants said that their school friends or classmates did that were not included in their own activity list, which was also acquired during follow-up interviews.

These activities fall into six categories adapted from activity codes used by Robinson and Godbey (1999): (1) study (reading, doing homework, labs, listening to English, using the Internet/computer for the purpose of study, and choosing classes), (2) other obligatory class-related activities (class assembly for meetings, having class pictures taken, required morning exercise in sports fields, attending roll-call on Sunday nights, and cleaning up the classroom), (3) paid work (tutoring and working for the logistics department on campus), (4) house work (cleaning dorms, fetching hot water, hand-washing clothes, and shopping for necessities), (5) personal needs and care (eating and drinking, sleeping and napping, washing and taking a shower, and visiting a doctor), and (6) discretionary time beyond the time needed for the obligatory activities. In this study, fifty-eight items of discretionary time activities were reported by participants. For simplicity, these activities are presented in Table 1 under four sub-categories: Entertainment/Social, Organizational, Recreation, and Communication, which Robinson and Godbey (1999) used to classify free time activities.

\subsubsection{Most Common Discretionary Time Activities and Reasons for These Choices}

During the interviews, participants were asked to identify the most common discretionary time activities among college students based on their observations. From their responses, the following themes emerged: sports (playing soccer, basketball, volleyball, ping-pong, badminton, tennis, and jogging, as well as walking), Internet use (chatting, watching movies, reading news; playing computer games on the Internet), window-shopping, reading and studying for pleasure, socializing (chatting and talking with friends in person, 
Table 1 An inventory list of discretionary time activities of college students in China

\begin{tabular}{|c|c|c|c|}
\hline Entertainment/Social & Organizational & Recreation & Communication \\
\hline $\begin{array}{l}\text { Dating } \\
\text { Dinner parties } \\
\text { (including birthday } \\
\text { parties) } \\
\text { Drinking and fighting } \\
\text { (during SARS) } \\
\text { Eating with friends } \\
\text { Hanging out with } \\
\text { friends } \\
\text { Listening to radio, } \\
\text { music or songs } \\
\text { Singing with friends } \\
\text { Taking pictures with } \\
\text { friends } \\
\text { Visiting friends or } \\
\text { family } \\
\text { Watching movie and } \\
\text { TV series on } \\
\text { computer } \\
\text { Watching movie in } \\
\text { auditorium } \\
\text { Watching TV }\end{array}$ & $\begin{array}{l}\text { Duty as a student leader in } \\
\text { class } \\
\text { Duty in a student } \\
\text { organization or } \\
\text { association } \\
\text { Political Party related } \\
\text { activities } \\
\text { Working in a university } \\
\text { administrative office }\end{array}$ & $\begin{array}{l}\text { Aerobics } \\
\text { Biking } \\
\text { Calligraphy } \\
\text { Cooking } \\
\text { Dancing } \\
\text { Dining out } \\
\text { Hiking } \\
\text { Jogging/running } \\
\text { Playing badminton } \\
\text { Playing basketball } \\
\text { Playing cards } \\
\text { Playing Chinese chess } \\
\text { ("Xiangqi”) } \\
\text { Playing computer games } \\
\text { Playing Go ("Weiqi") } \\
\text { Playing hula-hoop (SARS) } \\
\text { Playing kick-shuttle (SARS) } \\
\text { Playing mahjong (a board } \\
\text { game) } \\
\text { Playing piano } \\
\text { Playing ping-pong } \\
\text { Playing soccer } \\
\text { Playing tennis } \\
\text { Playing volleyball } \\
\text { Photography } \\
\text { Roller-skating } \\
\text { Rope-skipping } \\
\text { Swimming } \\
\text { Traveling in China } \\
\text { Trying on clothes } \\
\text { Walking for pleasure } \\
\text { Watching others play a } \\
\text { basketball game } \\
\text { Watching others play chess } \\
\text { Window-shopping } \\
\text { Prying }\end{array}$ & $\begin{array}{l}\text { Attending speeches } \\
\text { Chatting with friends } \\
\text { Listening to radio } \\
\text { (other than music } \\
\text { and songs) } \\
\text { Reading for pleasure } \\
\text { (newspapers, } \\
\text { magazines, novels, } \\
\text { cartoons, or other } \\
\text { books) } \\
\text { Talking on the phone, } \\
\text { or text messaging } \\
\text { using a cell phone } \\
\text { Talking with teachers } \\
\text { Thinking or } \\
\text { reminiscing } \\
\text { Using Internet } \\
\text { (chatting, checking } \\
\text { email, posting, } \\
\text { reading news, or } \\
\text { browsing web } \\
\text { pages) } \\
\text { Watching news on TV } \\
\text { Writing diary }\end{array}$ \\
\hline
\end{tabular}

Categories were adapted from activity codes used by Robinson and Godbey (1999). Activities under each category were presented in alphabetical order. Although not included in the above four categories, reading and studying for class (study) and part time jobs (paid work) were sometimes considered discretionary time activities by participants

including visiting with friends, hanging out with friends, and eating with friends), dating, involvement with student organizations, entertainment (e.g., watching movies in the auditorium on campus), and playing cards. It can be seen in Table 1 that these themes fall into all four sub-categories of discretionary time activities. Part-time jobs (e.g., tutoring and working as a sales representative) and reading and studying for class, although usually considered obligatory activities and thus not included in the four categories presented in Table 1, also emerged as two themes. Possible explanations include the possibility that some students chose to spend more time studying beyond requirements for self-fulfillment, and some students took part-time jobs not mainly for financial necessities but learning experiences.

To understand why these activities were popular choices among college students, participants were asked to offer their opinions and explanations. Main themes (reasons) 
emerged from the responses of participants such as age and stage of life, natural tendency, beneficial outcomes, convenience and accessibility, emotional needs, learning and improving abilities, and boredom. These themes are presented in Table 2, along with popular discretionary time activities and selected illustrating quotes.

\subsubsection{Activities on which Participants Spent the Most Discretionary Time and Self-Reported Reasons}

To further understand the reasons behind the choices for discretionary time use, time diaries were reviewed to identify activities that appeared to occupy a considerable amount of each participant's time, and each participant was asked why he or she chose to spend time that way. Responses from participants were analyzed and presented in Table 3. In comparison to reasons offered for general popular activities, these self-reported reasons for their own discretionary time use were more detailed.

\subsection{Impact of SARS: Constraint and/or Facilitator}

To examine how SARS affected participants' lives, they were asked about how they spent their discretionary time both before and after the appearance of SARS and subsequent restrictions imposed by university officials. It was assumed that SARS would severely constrain students' activities because they were confined to campus. Indeed, one salient constraint mentioned by all participants was suspension of off-campus activities that occurred frequently before the sealing of the school, such as window-shopping, visiting friends or family, eating out, going to an Internet café, tutoring, going to classes off campus, and other recreational activities such as roller-skating and photography. Although two students indicated they were severely depressed as a result of the restrictions, most participants stated they got used to it after the first couple of weeks.

Despite the suspension of off-campus activities, half of the participants clearly stated that their daily life was not changed by SARS, while the other half even mentioned positive changes. To make sense of this, a close examination of the profiles of participants was conducted, which revealed that participants who said their daily life was not changed by SARS could be classified into two groups: the no-change actives and the no-change inactives, whereas participants who stated that SARS did change their daily life in certain ways could also be classified into two groups: the change commuters and the change transformatives.

\subsubsection{No-Change Actives}

The no-change actives include five men who had been actively involved in physical activities and/or student organizations on campus before SARS occurred; they continued to be active during the sealing of the school. All five participants in this group claimed that there was no change in their daily life as a result of SARS. "Life was similar to the time before SARS," said Liusha, a confident 22-year-old sophomore who enjoyed playing soccer a lot and working for the Student Affairs office-an opportunity he won through intense competition against other student applicants. Hongyi, a 21-year-old sophomore who loved the "excitement" of active sports, Muzi, a first-year student aged 22 who worked at the university Radio Station, Tongping, a 20-year-old student leader in his 
Table 2 Most common discretionary time activities among Chinese college students as observed and explained by participants

\begin{tabular}{|c|c|c|}
\hline Activities & $\begin{array}{l}\text { Explanations for the } \\
\text { popularity }\end{array}$ & Selected quotes for illustration \\
\hline \multirow{4}{*}{$\begin{array}{l}\text { Sports (12) } \\
\text { (Soccer, basketball, } \\
\text { volleyball, ping- } \\
\text { pong, badminton, } \\
\text { tennis, jogging, } \\
\text { walking) }\end{array}$} & Age and the stage of life & $\begin{array}{l}\text { "We are young people in our twenties so we like } \\
\text { sports." (Jianchun, man, 25) }\end{array}$ \\
\hline & Natural tendency & "Boys like sports." (Xiaomin, woman, 23) \\
\hline & Beneficial outcomes & $\begin{array}{l}\text { "Sports makes me happy and strong." (Yiling, } \\
\text { woman 23) }\end{array}$ \\
\hline & $\begin{array}{l}\text { Convenience and } \\
\text { accessibility }\end{array}$ & $\begin{array}{l}\text { "[Playing ball games and walking] are } \\
\text { convenient... and did not require much } \\
\text { investment." (Xiaoyun, woman, 23) }\end{array}$ \\
\hline \multirow{6}{*}{$\begin{array}{l}\text { Computer use (9) } \\
\text { (On-line chatting, } \\
\text { watching movies, } \\
\text { reading news on the } \\
\text { Internet; playing } \\
\text { computer games) }\end{array}$} & Learning & $\begin{array}{l}\text { "You can find all sorts of information there [on } \\
\text { the Internet]." (Lulu, woman, 21) }\end{array}$ \\
\hline & Boredom & $\begin{array}{l}\text { "Using the Internet kills some time. We go on } \\
\text { the Internet because we feel bored." (Xieling, } \\
\text { woman, 20) }\end{array}$ \\
\hline & $\begin{array}{l}\text { Convenience and } \\
\text { Accessibility }\end{array}$ & $\begin{array}{l}\text { [Reading, Internet, visiting with friends and } \\
\text { window-shopping are] "convenient, } \\
\text { affordable, and within one's control." (Lilin, } \\
\text { woman, 20) }\end{array}$ \\
\hline & Emotional needs & $\begin{array}{l}\text { "[Using the internet can help one] forget about } \\
\text { the unhappiness and frustrations in real life." } \\
\text { (Jianchun, man, 25) }\end{array}$ \\
\hline & Natural tendency & $\begin{array}{l}\text { "Boys just like playing computer games." } \\
\text { (Zhaoqian, woman, 20) }\end{array}$ \\
\hline & Addiction & $\begin{array}{l}\text { "It's easy for people to feel addicted to it, be it } \\
\text { playing computer games or chatting [on- } \\
\text { line]." (Tongping, man, 20) }\end{array}$ \\
\hline \multirow[t]{4}{*}{ Window-shopping (6) } & Beneficial outcomes & $\begin{array}{l}\text { "[Sports, dating, window-shopping] are } \\
\text { relaxing, especially mentally relaxing." } \\
\text { (Hongyi, man, 21) }\end{array}$ \\
\hline & Natural tendency & $\begin{array}{l}\text { "Girls just like window-shopping." (Zhaoqian, } \\
\text { woman, 20) }\end{array}$ \\
\hline & $\begin{array}{l}\text { Convenience and } \\
\text { accessibility }\end{array}$ & $\begin{array}{l}\text { "[Playing ball games and window-shopping are] } \\
\text { the only accessible and affordable activities on } \\
\text { campus." (Xuewei, woman, 22). }\end{array}$ \\
\hline & Vanity & $\begin{array}{l}\text { "Young people want to look fashionable." } \\
\text { (Lulu, woman, 21) }\end{array}$ \\
\hline \multirow{2}{*}{$\begin{array}{l}\text { Reading and studying } \\
(6) \\
\text { (For pleasure and for } \\
\text { class) }\end{array}$} & Beneficial outcomes & $\begin{array}{l}\text { "[Reading magazines, newspapers and novels in } \\
\text { the library] is entertaining."(Xiaomin, man, } \\
23 \text { ) }\end{array}$ \\
\hline & $\begin{array}{l}\text { Convenience and } \\
\text { accessibility }\end{array}$ & $\begin{array}{l}\text { [Reading, Internet, visiting with friends and } \\
\text { window-shopping are] "convenient, } \\
\text { affordable, and within one's control." (Lilin, } \\
\text { woman, 20) }\end{array}$ \\
\hline $\begin{array}{l}\text { Interacting with } \\
\text { friends (5) }\end{array}$ & Beneficial outcomes & $\begin{array}{l}\text { “...Walking and chatting... are relaxing } \\
\text { activities." (Awen, man, 24) }\end{array}$ \\
\hline $\begin{array}{l}\text { (Chatting, talking, } \\
\text { visiting, hanging out } \\
\text { and eating with } \\
\text { friends) }\end{array}$ & $\begin{array}{l}\text { Convenience and } \\
\text { accessibility }\end{array}$ & $\begin{array}{l}\text { [Reading, Internet, visiting with friends and } \\
\text { window-shopping are] "convenient, } \\
\text { affordable, and within one's control." (Lilin, } \\
\text { woman, 20) }\end{array}$ \\
\hline
\end{tabular}


Table 2 continued

\begin{tabular}{|c|c|c|}
\hline Activities & $\begin{array}{l}\text { Explanations for the } \\
\text { popularity }\end{array}$ & Selected quotes for illustration \\
\hline \multirow[t]{3}{*}{ Dating (5) } & Age and the stage of life & $\begin{array}{l}\text { "It is related to the psychological need for a } \\
\text { romantic relationship at this stage of life." } \\
\text { (Liusha, man, 22) }\end{array}$ \\
\hline & Emotional needs & "Everyone longs for love" (Yiling, woman, 23) \\
\hline & Beneficial outcomes & $\begin{array}{l}\text { "[Sports, dating, window-shopping] are } \\
\text { relaxing, especially mentally relaxing." } \\
\text { (Hongyi, man, 21) }\end{array}$ \\
\hline $\begin{array}{l}\text { Involvement with } \\
\text { student } \\
\text { organizations (2) }\end{array}$ & $\begin{array}{l}\text { Learning and self- } \\
\text { improvement }\end{array}$ & $\begin{array}{l}\text { "...students were encouraged to not only have } \\
\text { knowledge but also abilities... it was easy to } \\
\text { draw a direct link between ability and } \\
\text { participation in student organizations." (Muzi, } \\
\text { man, 22) }\end{array}$ \\
\hline $\begin{array}{l}\text { Entertainment (1) } \\
\text { (Watching movies in } \\
\text { the auditorium) }\end{array}$ & Natural tendency & "People Love movies." (Jinsheng, man, 25) \\
\hline Playing cards (1) & Boredom & $\begin{array}{l}\text { "[We have] so much free time at week-ends but } \\
\text { don't know what to do, so we play cards." } \\
\text { (Xiaomin, man, 23) }\end{array}$ \\
\hline Part-time jobs (1) & $\begin{array}{l}\text { Learning and self- } \\
\text { improvement }\end{array}$ & $\begin{array}{l}\text { "[Students sought to] improve abilities through } \\
\text { practical work experiences." (Yiling, woman, } \\
23 \text { ) }\end{array}$ \\
\hline
\end{tabular}

Numbers in parentheses under Activities indicate the number of participants who referred to each activity

freshmen class, and Xiaomin, a 23-year-old junior who enjoyed playing soccer, basketball and board games with friends, all expressed similar perceptions.

Although not perceiving any SARS-caused changes in daily life, when asked further about any possible changes they wanted to maintain, two participants of this group offered information that could be interpreted as positive changes. Hongyi, the 21-year-old who had always been active in sports, after thinking carefully upon the question, said: "In the period of SARS, I spent my unoccupied time studying and reading more. Over this period, studying gave me a sense of fulfillment. I will take more time to read, or to study." Xiaomin (23, junior), another man who did not perceive any changes in his daily life, stated that he did experience a change "in the respect of will power. Confined inside here, I become stronger. Never before had I been confined so long. Now I feel it does not matter much to me whether I am confined or not. It is all the same."

\subsubsection{No-Change Inactives}

The no-change inactives include two women and one man who had not been actively involved in any sports or student organizations; although they might have tried some physical activities during the sealing of school, they did not maintain the change and returned to their former sedentary lifestyle. Xuewei (23, junior) and Xieling (20, sophomore), two women who had always centered their college lives around study, did not perceive much change in their daily lives, although both of them tried dancing briefly when such opportunities were plentiful and easily accessed during the sealing of the school.

Awen, a 24-year-old junior who defined himself as a loner, also tried some activities temporarily, but like Xuewei and Xieling, did not continue these activities: "In the period 
Table 3 Activities participants spent the most discretionary time on and self-reported reasons for choices

\begin{tabular}{|c|c|}
\hline Activities & Self reported reasons \\
\hline Chatting/socializing (15) & $\begin{array}{l}\text { Social needs } \\
\text { Pleasure } \\
\text { Environmental conditions (e.g., because of no air-conditioning in } \\
\text { dorm, many stayed outside in the evening to "be cool," and } \\
\text { chatting happened during this time) } \\
\text { Boredom }\end{array}$ \\
\hline Study (13) & $\begin{array}{l}\text { Exam } \\
\text { Having nothing else to do than study } \\
\text { Employment pressure } \\
\text { Responsibility to family } \\
\text { Acquirement of knowledge } \\
\text { Habit }\end{array}$ \\
\hline Physical exercises/sports (11) & $\begin{array}{l}\text { Enjoyment } \\
\text { Improvement of appearance or personal attraction } \\
\text { Accessibility } \\
\text { Socializing } \\
\text { Family tradition } \\
\text { SARS }\end{array}$ \\
\hline Reading for pleasure (9) & $\begin{array}{l}\text { Enjoyment } \\
\text { Habit } \\
\text { Staying current with news } \\
\text { Recharging one's self }\end{array}$ \\
\hline Computer use (6) & $\begin{array}{l}\text { Escaping the real world } \\
\text { Interest in computers } \\
\text { Inaccessibility of other activities }\end{array}$ \\
\hline Playing cards/Chinese chess (5) & $\begin{array}{l}\text { Boredom } \\
\text { Environmental condition (e.g., It was too hot to sleep, so they } \\
\text { played cards) }\end{array}$ \\
\hline $\begin{array}{l}\text { Listening to radio/music (4) } \\
\text { (A dominant secondary activity when } \\
\text { staying in the dorm room) }\end{array}$ & $\begin{array}{l}\text { Interest } \\
\text { Enjoyment } \\
\text { Relaxation } \\
\text { Emotional expression } \\
\text { Learning }\end{array}$ \\
\hline Shopping/Window-Shopping (4) & $\begin{array}{l}\text { Relaxation } \\
\text { Enjoyment }\end{array}$ \\
\hline Organizational activities (3) & Improve career-related abilities \\
\hline Writing diary (1) & $\begin{array}{l}\text { Interest in writing } \\
\text { Desire to "keep records of feelings" }\end{array}$ \\
\hline
\end{tabular}

Numbers in parentheses indicate the number of participants who referred to each activity

of SARS, we kicked shuttle. I was very good at it. I was good at skipping rope, too. I am not playing them nowadays. Now that SARS is over, no one at present plays them anymore." As a result, Awen did not think SARS changed his daily life.

\subsubsection{Change Commuters}

The change commuters include two women who had relatives or families in town. Compared to other students, they had a very busy social life in terms of interactions with families and friends outside campus, and did not have to live in the dorm all the time. 
Although they perceived little change in their on-campus activities, they came to appreciate campus life and said they would not totally return to their former lifestyles. Lulu (20, female, junior), who used to spend a lot of time visiting friends and family, developed a new appreciation for the "regular life" on campus. Yiling, a thoughtful 23-year-old senior, even thought of her previous frequent outings as a "waste of time":

Never had I lived so long within a single confined area. Yet after 2 months of such life, I have felt that such kind of life could be lived, and there was nothing bad about it. I even think what I did before like going window shopping and eating out was a waste of time. I am capable of living this kind of life, and I am okay. As long as I have a few close friends, I do not have to return to the former lifestyle. Really. Before, one or 2 days on campus without going out would have made me depressed. I felt, how could I have stayed for such a long time in this place without seeing the exciting world outside? So I had to go out. However, now I don't think that way. I think it is okay.

\subsubsection{Change Transformatives}

The change transformatives, the largest group, included two men and four women who had not been active in physical activities or other leisure activities, but became active in such activities during SARS and developed strong interest in them. They said they would keep these changes even though SARS was over. Jinsheng, a 25-year-old male senior, said joyfully: "I don't think I can restore [to former life style]. ... I did not like sports before; just due to SARS, I took to sports (chuckle). I want to keep this new hobby." Likewise, Yeke (19, first-year), a young woman who was seldom involved in physical activities before, said: "During the period of SARS, I began to play sports, such as skipping rope, which I did not play much even when I was a kid... Now I seemed to take to sports." Xiaoyun (23, female, senior) also developed a newfound interest in physical activities: "I feel I've changed so much recently that I am unlikely to live in the previous way. I really seldom took part in sports before, but now I feel I like sports." Lilin (20, junior) and Zhaoqian (20, sophomore) were two other young women who had newly found interest in physical activities during SARS. On the other hand, Jianchun (25, male, senior) developed a new interest in music: "Before I seldom listened to music. During the period of SARS, I kept listening to music, frequently, and the result is I have become interested in many music styles."

Via discretionary time activities during the sealing of school, potentially enduring positive social relationships also developed for some members of this group. For example, Lilin (20, female, junior) felt more interaction with her classmates improved her life: "I used to be so occupied with my own things that I did not have time to interact with my classmates. Now, being sealed in here, I often go find classmates to hang out together, and then I realize that I can learn a lot from communicating with them. I feel this kind of life is good." Jinsheng, a senior who started physical activities during SARS also enjoyed his new social acquaintances: "Because of sports I have made many new friends (laugh). 'Sports Baby' who I mentioned previously was one of them... I got to know her through playing ping-pong during the sealing of school."

During a time when the SARS crisis seemed to impose serious constraints on these students' lives, what facilitated these positive changes? Based on the theoretical framework of affordance, it seems that university strategies and social affordance on campus played an important role in facilitating new interest in physical activities with multiple benefits. 
For example, in order to motivate the students to build their bodies and fight against SARS, the university made great efforts to inform students about the health benefits of physical activities. At the same time, programs were offered to encourage participation in physical activities. The university also increased opportunities by providing equipment and supplies, such as a kick-shuttle (similar to a hacky-sack) and a jump rope, to each dorm room. These strategies seemed to have successfully motivated some previously inactive students to participate in physical activities. By participating, many students found new interests and remained active. Jinsheng (25) demonstrated the effects of his increased knowledge teamed with opportunity:

I didn't like sports (laugh). I hated sweating. Because of SARS, the government publicized the significance of enhancing physical conditions, and we did come to like physical exercise... There was a joke going round about the types of people died because of SARS... (laugh) I belonged to the type who exhausted themselves to death by doing sports... The school also gave each dorm room many things to play with, such as kick-shuttles and jumping ropes.

Yeke (19) found new talents due to encouragement to participate in more activities: In the period of SARS, lots of physical activities were held on campus, organized by school as well as by class, like mini dance corridor, international standard dance, aerobics, ping-pong, badminton, so we often went out to play... Now I seem to take to sports, playing basketball, ping-pong. I did not know how to play those; I never touched a ping-pong ball before.

When more students came out for physical activities, it provided a welcoming social atmosphere for those who were otherwise uncomfortable participating in physical activities. According to Jinsheng (male, 25), "it was bustling with activities on campus during that period. Dancing in the evening. The music fountain became an open ballroom where a lot of people gathered to dance." Zhaoqian, a previously inactive 20 -year-old young woman, said that during SARS, "as soon as we returned to the dorm in the evening, we began to play sports, until the dorm building was about to close... We went out to play basketball... Sometimes we girls skipped rope in the hall way." That welcoming atmosphere could also be sensed through the description of Xiaoyun (female, 23), a quiet senior who came to like sports during SARS:

Those days it was very hot, and no one would like to come outside in the afternoon. After 6:00 PM, students began to play things such as badminton or hula-hoop. From 6:00 to 10:30 pm, everywhere on campus, including all over the roads, people were seen playing badminton. On the ground around the music fountain, many were throwing sand-sack, jumping rope, and skipping a long rope in groups. What fun! ...During that period, sometimes I felt that I seem to become much younger.

A welcoming social atmosphere, along with the influence of peer behavior, fostered interests and encouraged physically inactive students to try new activities. Yeke, age 19, described her realization of taking action and experiencing benefits by adapting to changes with positive benefits:

During that period we almost went out playing every day. In terms of sports, now that you start doing it now and then, you become interested in it (laugh) ... I started to learn gradually, everybody went to learn, for many did not know how to play, and then we went to learn together, and then become interested. 


\section{Discussion}

This qualitative study has drawn a picture of discretionary time choices made by students in a big Chinese university, reasons provided by participants for popular discretionary time choices, and the impact of SARS on their daily life, especially during their discretionary time. Future studies offer the opportunity for understanding the cultural orientation shift that occurs among Chinese college students during this transition to adulthood and to explore their changing leisure patterns, as well.

\subsection{Discretionary Time Activities}

Although the activity inventory list generated in this study may be somewhat constrained due to the small sample size, participants were asked to describe not only their own activities, but discretionary time activities they observed or knew of that were participated in by other students (whether they knew those students in person or not). We are confident that the activity inventory list is fairly inclusive for this study group. It has provided a base for instrument development for more extensive survey research and monitoring in the future. The seemingly small pool of activities found in this study is consistent with the observation made by the majority of participants that they spent time similarly with their friends and classmates when asked to compare their way of spending time with other students (not just friends) in class. This is likely at least partly due to the purposeful sampling (combined with snowball sampling) method that aimed to obtain ordinary cases in order to understand the ordinary life of Chinese college students, even though the sampling method also ensured a diversity of students with different backgrounds were recruited. The small pool of activities may also indicate that opportunities and programs provided by the university were indeed limited and could be improved.

It should be noted that the activity list might be context sensitive. For example, when studying leisure patterns of college students in Taiwan, Yen (1995) used 59 items in his survey. Twenty-four items that occurred on his list were not found in the inventory list generated in this study, including watching video tapes, religious activities, billiards (pool), picnicking, camping, fishing, boating, going to the beach, scouting, driving (car/motorcycle), Chinese gymnastics, Yoga, bowling, Karaoke, joining a study group, watching MTV, visiting museums/galleries, collecting (stamps, etc.), social service, painting, making handicrafts, birds watching, gardening, and visiting a foreign country. On the other hand, twelve items that occurred in this list were not included on Yen's (1995) list, such as using the Internet, watching movie discs, attending dinner parties/ birthday parties, taking pictures with friends, drinking and fighting, talking on the phone/ text-messaging on a cell phone, writing in a diary, cooking, trying on clothes, playing kick shuttle, playing hulahoop, and political-party related activities.

The reasons behind these differences may include different physical environments, technology change over time, and different socio-economic situations. For example, the specific urban Chinese college context in this study may limit the range of outdoor activities. Some activities, such as boating, fishing, going to the beach, camping and picnicking were more accessible in Taiwan than in the city where participants in this study attended the university. The Internet, cell phone, and movie discs were not common technology in the mid 1990's when Yen's research was conducted. And, most Chinese college students would not have the resources or opportunities to enjoy activities such as driving a car or motorcycle or to visit a foreign country. 
To generate a more comprehensive list of activities and get a more broad view of Chinese college students' activity patterns, future research could include universities from different locations, and include universities at different levels and emphases (i.e., arts, sciences, business, music, law, and foreign languages). Future research on Chinese college students' discretionary time activity patterns must also be very sensitive to emerging influences. With such rapid change in China and changing influences on Chinese university students, future research will need to allow for and be designed to capture changes in Chinese university students' discretionary time activities.

\subsection{Institutionally-Imposed Constraints and Affordance}

Results suggest that despite the constraints imposed by SARS, particularly the suspension of off-campus activities, some students did not perceive a change of daily life as a result, while others even perceived positive changes in attitudes and behavior. This real-life exploration of the effects of structural constraints on Chinese college student decisions is in contrast to some leisure constraint research on Chinese college students which is more hypothetical in nature (see for example Walker et al. 2007), and therefore some unexpected positive effects of structural constraints emerged. Leisure affordance theory is particularly relevant to understanding these findings on positive changes during SARS.

Affordance is defined by the constraints as well as the possibilities for action that are present in a particular situation (see Greeno 1994; Kleiber et al. 2005; Mannell and Kleiber 1997). As Kleiber et al. (2005) pointed out, while constraints are normally negative factors, a constraint may sometimes be accompanied by an affordance. Affordance represents the environmental conditions (possibly including constraints) that elicit motivation (interest, enthusiasm, approach, etc.) in conjunction with perceived needs. In this study, participants felt a need to do something to prevent the infection of SARS. However it was the university's public relations efforts emphasizing "building your body to fight against SARS" which initially motivated many students to take part in physical activities. Provision of equipment and supplies made the activities more tempting and accessible. Findings of this study support (a) the belief that affordance was only fully perceived through actions that brought environmental conditions into interaction with the individual, and (b) the importance of social affordance (Kleiber et al. 2005). As shown in this study, for some participants, changing social situations were instrumental in affording and sustaining new leisure behaviors; however, some participants who got involved in physical activities due to the inviting social atmosphere discontinued their participation when the atmosphere disappeared.

As Kleiber et al. (2005) argued, although constraints are negative factors, examining opportunities offered through the perception of leisure affordance may bring new insights to the process and provide new directions for research. There is potential for more research that utilizes the construct of leisure affordance to understand allocation of discretionary time, especially when positive outcomes from organized programs or interventions are involved.

\subsection{Future Expectations}

Obligatory time for working adults and college students seems very different, though with recent transitions in higher education in China, they may be coming closer together (e.g., requirements to pay tuition, more dependence on part-time jobs, more highly educated work force emerging, etc.). Discretionary time of young people is changing and will 
continue to change with continuing advances in technology, changes in prescribed skills to be mastered, and the growing realization of the important role that time spent in college may play in the development of emerging adults as they approach a new set of obligations to society, to family, to employers, and to themselves. Individual and social welfare can be linked to influences over discretionary time activity choices. Greater realization of these influences increase our chances of making better individual and collective choices.

This research should raise awareness of quality of life issues for Chinese college students and lead to more conscientious decision making about discretionary time opportunity planning by college administrators. Recognition that Chinese college students are experiencing substantial shifts in obligatory time commitments as well as nonobligatory opportunities could be an important foundation for planning student support services. Additionally, imposing some crisis-induced institutional constraints, reinforced by appropriate planning for increased nonobligatory activities, can produce very positive results that could contribute to quality of life perceptions into later stages of life for these students.

\section{References}

Andorka, R. (1987). Time budgets and their uses. Annual Review of Sociology, 13, 149-164.

Cheng, Y., \& Zhou, J. (2003). Gaodeng jiaoyu tixi zhubu changkai "zizhu xuanze zhuanye" kongjian [Higher education system gradually opens up to let students "choose own majors"]. Retrieved July 26, 2008, from http://news.blcu.edu.cn/detail.asp?id=3002.

Crawford, D., Jackson, E., \& Godbey, G. (1991). A hierarchical model of leisure constraints. Leisure Sciences, 13, 309-320.

Creswell, J. W. (1998). Qualitative inquiry and research design: Choosing among five traditions. Thousand Oaks, CA: Sage Publications.

Duan, X-R. (2003). Chinese higher education enters a new era. Academe, Nov/Dec 2003. Retrieved December 22, 2007, from http://findarticles.com/p/articles/mi_qa3860/is_200311/ai_n9304718.

Gibson, J. J. (1977). The theory of affordances. In R. Shaw \& J. Bransford (Eds.), Perceiving, acting and knowing: Toward an ecological psychology (pp. 67-82). Hillsdale, NJ: Erlbaum.

Goodin, R. E., Rice, J. M., Bittman, M., \& Saunders, P. (2005). The time-pressure illusion: Discretionary time versus free time. Social Indicators Research, 73, 43-70.

Greeno, J. G. (1994). Gibson's affordances. Psychological Review, 101, 336-342.

Henderson, K. A. (1997). A critique of constraints theory: A response. Journal of Leisure Research, 29, $453-457$.

Howard, A. (1986). College experiences and managerial performance. Journal of Applied Psychology, 71, $530-552$.

Jackson, E. (2000). Will research on leisure constraints still be relevant in the twenty-first century? Journal of Leisure Research, 32, 62-68.

Jackson, E., Crawford, D., \& Godbey, G. (1993). Negotiation of leisure constraints. Leisure Sciences, 15(1), $1-11$.

Kamps, B. S., \& Hoffmann, C. (2003). SARS Reference. Retrieved July 6, 2008, from http://www. sarsreference.com/.

Keku xuexi, baoxiao zuguo [Study hard to serve our country]. (2005, April 20). Guangming Daily, p. A1.

Kleiber, D., Wade, M., \& Loucks-Atkinson, A. (2005). The utility of the concept of affordance for leisure research. In E. L. Jackson (Ed.), Constraints to Leisure (pp. 233-243). State College, PA: Venture.

Krueger, A. B., Kahneman, D., Fischler, C., Schkade, D., Schwarz, N., \& Stone, A. A. (2009). Time use and subjective well-being in France and the U.S. Social Indicators Research, 93, 7-18.

Kuh, G. D. (1995). The other curriculum: Out-of-class experiences associated with student learning and personal development. Journal of Higher Education, 66, 123-155.

Larmer, B. (2006). Manchurian mandate. National Geographic, 210, 42-73.

Lewis, J., \& Xue, L. (2003). Social changes and political reform in China: Meeting the challenge of success. The China Quarterly, 2003, 926-942.

Mannell, R. C., \& Kleiber, D. A. (1997). A social psychology of leisure. State College, PA: Venture Publishing, Inc. 
Moffatt, M. (1988). Coming of age in New Jersey: College and American culture. New Brunswick, NJ: Rutgers University Press.

Robinson, J. P. (1977). How Americans use time. New York: Praeger.

Robinson, J., \& Godbey, G. (1999). Time for life: The surprising ways Americans use their time (2nd ed. ed.). University Park, PA: The Pennsylvania State University Press.

Samdahl, D., \& Jekubovich, N. (1997). A critique of leisure constraints: Comparative analyses and understandings. Journal of Leisure Research, 29, 430-452.

Smyth, R., Nielsen, I., \& Zhai, Q. (2010). Personal well-being in urban China. Social Indicators Research, 95, 231-251.

Tao, S., Dong, Q., Pratt, M. W., Hunsberger, B., \& Pancer, S. M. (2000). Social support: Relations to coping and adjustment during the transition to university in the People's Republic of China. Journal of Adolescent Research, 15, 123-144.

Walker, G., Jackson, E., \& Deng, J. (2007). Culture and leisure constraints: A comparison of Canadian and Mainland Chinese university students. Journal of Leisure Research, 39, 567-590.

Yen, M. (1995). The role of leisure among students at normal university/teachers colleges in Taiwan-An exploratory investigation. Unpublished doctoral dissertation, The Pennsylvania State University, PA. 